\title{
Narratives of Sri Lankan Displaced Tamils Living in Welfare Centers in Jaffna, Sri Lanka
}

\author{
Diotima Chattoraj \\ Faculty of Arts and Social Sciences, \\ University of Brunei Darussalam, Brunei Darussalam
}

\begin{abstract}
This article addresses the kind of attachment that the Sri Lankan Tamil IDPs, refugeed in the welfare centers of Jaffna, have to their $U_{r} /$ homes in the post-war era. This article is to explore, how they describe the meaning of attachment to their Ur even after two decades of displacement and how this is related to the negotiations with displacement. To understand this relationship, I used the concept of attachment to analyze my collected data. The qualitative materials are drawn from the data collected during my ethnographic field-visit in Jaffna in February-March 2013. The focus is on narrative interviews with IDPs staying at the welfare centers in Jaffna. This article discusses in detail the narrative of an IDP who spoke on behalf of several others

Received:

December 12, 2018

Revised:

December 23, 2018

Accepted:

January 24, 2019

\section{Corresponding author:}

diotima.chattoraj@udb.edu.bn who were in the same situation and staying at the center since the early 1990s. From his narrative, I show their intense sense of attachment not only to their $U_{r}$ but also to the memories and emotions which are related to their $U_{r}$. I argue that the meaning of $U_{r}$ and attachment to it, has remained unchanged for this group of population in Jaffna due to socio-economic reasons and aspirations to a good life.
\end{abstract}

Keywords: Homes; Attachment; IDPs; Tamil; Jaffna.

\section{Introduction}

Sri Lanka experienced 26 years of vicious fighting between the Sri Lankan government and the Liberation Tigers of Tamil Eelam (LTTE). ${ }^{1}$ The war which started in July 1983, came to an end in May 2009, when the Government declared victory over the LTTE was killing most of their leaders. The purpose of the war witnessed the death of hundreds, displacement of more than a million, both internally and externally from the NorthEast and destruction of physical and human infrastructures. The vast majority of Tamils were housed in welfare centers $^{2}$ either in Sri Lanka as Internally Displaced Persons (IDPs) ${ }^{3}$ or in Southern India as refugees, while others migrated to Western Europe, North America, and Australia to join the Tamil diaspora communities. According to the Ministry of Resettlement ${ }^{4}$, as of 31st July 2016, there are around six welfare centers in Jaffna housing around 3261 IDPs. They are unable to access their lands due to 'military occupation.'

This paper addresses the kind of attachment that the Sri Lankan Tamil IDPs, refugeed in the welfare centers of Jaffna, have to their $U_{r}^{5} /$ homes in the post-war era. Here, I aim to explore, how they describe the meaning of attachment to their homes even after two decades of displacement and how this is related to the

${ }^{1}$ Several militant groups among the Tamils emerged since the 1950s, the notable being the LTTE, which was formed in 1975 under the leadership of Prabhakaran.

${ }^{2}$ In Sri Lanka, "Welfare Centres" mean a public or private premise that house the IDPs. The term has been used regardless of the duration of displacement.

${ }^{3}$ Guiding Principles on Internal Displacement uses the definition “internally displaced persons are persons or groups of persons who have been forced or obliged to flee or to leave their homes or places of habitual residence, in particular as a result of or in order to avoid the effects of armed conflict, situations of generalized violence, violations of human rights or natural or human-made disasters, and who have not crossed an internationally recognized State border."

${ }^{4}$ http://resettlementmin.gov.lk/site/index.php option=com_content\&view=article\&id=6\&Itemid=22 \&lang=en, Accessed on $3^{\text {rd }}$ May 2018.

${ }^{5} U_{r}$ is an everyday and often used Tamil word for 'homeland/village' and has been used extensively by Sharika Thiranagama in her book 'In My Mother's House' (2011). 
negotiations with movement. The qualitative data, in the form of narrative, semi-structured in-depth interviews, focused group discussions and participant observations are drawn from the data collected during my ethnographic field-visit in Jaffna in February-March 2013. The focus is on narrative interviews with IDPs staying at the welfare centers. Among the several IDPs interviewed ${ }^{6}$ at the centers, this article discusses one of the narratives which was living at a welfare center in Jaffna since the early 1990s. From his description, I show his intense sense of attachment not only to his Ur but also to the memories and emotions which are related to his Ur. I argue that for him, the idea of return is 'in recognition of an identity' with his Ur.

\section{Method}

Considering the purpose and type of research questions, I adopted a qualitative approach to study how the displaced persons conceptualize the notions of home and belonging. As emphasized by Cresswell (2003), the selection of my methodological tools was driven by the research question, hence used qualitative method approach. This method, as Pickbourn (2011: 12) emphasizes, provides a holistic understanding of complex issues and processes, and increase the likelihood of uncovering unexpected and sensitive issues that are relevant to uncovering casual relationships. Thus, its use helped to get a detailed view on how these returnees perceive displacement and return and relate with their homeland. With qualitative approach, the respondents got enough room to express and reveal their experiences and stories. They talk about their past lives, their experiences, aspirations and challenges after return to their places of origin.

My decision to concentrate on Jaffna developed because compared to other Northern regions, e.g. Kilinochhi, Vavuniya, Mullaitivu, Jaffna is not that much under military surveillance which makes access to the field possible in the first place. Secondly, Jaffna, is believed to be the heart of Tamil land (Tekwani, 2003). Also, it is the place where the most number of IDPs are refugeed at the welfare centers at present.

In-depth, informal and semi-structured interviews and observation were the primary methods regarding data collection. The samples varied in terms of gender, age, and class. The interview questionnaire was semi-structured in nature and was divided into two sections; The first section asked a number of demographic questions like, age, sex, marital status, family members, education, occupations, place of origin, etc.; The second section asked specific questions to the respondents which included their conceptualization of home, how they relate to their homeland, their experiences and idea of return.

The information put with careful and calculated efforts, to maintain ethics in this study. Respondents had been informed well beforehand about the purpose and technique of this work, including the nature of questions they would be asked. They were also told about the group of people who would be having access to the findings of my research and the means of its readings and publicization. Each of the respondents had been given the freedom to partake openly, and even refuse or withdraw participation from the research at any point in time (Scheyvens, 2014). Confidentiality was prioritized, and no private data are identifying the subjects has been reported or divulged (Kvale, 1996: 114). Convincing them that their real identities would not be revealed at any cost and hence, used pseudonyms in this article.

In addition to the interviews, the welfare center is a destination that has been visited quite a couple of times to observe about the daily lives of the IDPs. The informants helped with the easy access and continued to enhance the knowledge about the present status-quo of the center.

\section{$U_{r}$ and Attachment: The Concepts}

The concept of home among the Tamils has been wonderfully dealt with in the books of Daniel (1984), Fluid Signs: Being a Person the Tamil Way and Sharika Thiranagama (2011), In My Mother's House: Civil War in Sri Lanka. Traditionally, to the Sri Lankan Tamils, home or $U_{r}$ is their natal village on which they were born and nurtured. It forms the main basis of their identity as discussed by Thiranagama (2011: 18). $U_{r}$, in Jaffna, as identified by Daniel (1984: 102), also symbolizes one's 'kunam' or character that is necessary for social interaction. Moreover, persons belonging to the same $U_{r}$ share similar characteristics through their 'nourishment in the same soil' providing 'collective identification of people from that $U_{r}$ ' (Thiranagama, 2011: p. 18). They consider staying away from their $U_{r}$ as a form of supreme punishment that is much more severe compared to 'social death' (Cheran, 2007: 151).

${ }^{6}$ There were 30 in-depth interviews which have been conducted and four focus group discussions in the three welfare centers of Jaffna. These camps were randomly selected. The number of members vary in each of the welfare centers, I visited, from around 150-160 families. All of them are housed since 1990 and are not allowed to return to their original homes as they are currently occupied by the military. 
Additionally, Daniel's (1984: 62) research on $U_{r}$ in the South Indian villages establishes the fact that the Tamils get to know about their own identity only after having nurtured on its soil, eating food from there, and inhaling the air of his/her village. Therefore, the relationship between a 'Tamil and the soil of his $U_{r}$ is considered the most important among all others. This aspect is well researched in Thiranagama's book, which offers a significant contribution in the field of political anthropology and the ethnography of violence, particularly concerning the concepts of home and displacement. A number of issues have been investigated, namely, the effects of the protracted war on the meanings of $U_{r}$ amidst profound displacement, transformations of familial and generational experiences (Thiranagama, 2011:5), and the impact of the political violence on civilians executed by both the LTTE and the Sri Lankan state (Thiranagama: 18). Though there is lack of a simple and easy definition of $U r$, Daniel has defined it as a "named territory that is 1) inhabited by human beings who are believed to share in the substance of the soil of that territory, and 2) a territory to which Tamil cognitively orients himself at any given time" (Daniel, 1984: 63).

In a wider context, the book of Thiranagama focuses on the controversial and dramatic ending of the long civil war. Her main aim is to examine the position of the victims of the war and their 'historical and political trajectories' (Thiranagama, 2011: 19), which shape their ideas of home. She studies home as 'an everyday language of love, affection, sentiment and memory' (Thiranagama: 19). This study elucidates the various heart-rendering stories of eviction and portrays the narratives of Northern Muslims, focusing on their notions of $U_{r}$, discussing 'un-homeliness' and 'homeliness' at their present locations (Thiranagama, 2011: 19).

The author applies an innovative perspective on generations and generational divergences, focusing on the difference between young and old generations on experiences of war. For the elderly, memories of home create a strong desire to return to their $U$. By contrast, younger people are reluctant to return because of the painful memories they associate with their former homes at war times. In between, the middle generations are stuck with both memories of their homes and of eviction. The analysis confirms the problem of not being able to return, which is common to most of the Northern Muslims. The author wraps up her study by elaborating on the question of 'future homes; in Colombo where the minorities 'have homes but not a homeland', and their new homes do not correspond to the past one (Thiranagama, 2011:255).

The three dimensions, commonality, mutuality and attachment, that Pfaff-Czarnecka (2013) identifies as ways in which people construct their belonging are useful to this analysis. Nevertheless, I take up the third dimension, 'attachment', which refers to a deep and enduring emotional bond connecting individuals across time and space (Chattoraj, 2017, 2018; Ainsworth 1973; Bowlby 1969), it links people to material and immaterial worlds (Pfaff-Czarnecka, 2013: 17) making them belong to spaces and sites, to natural objects, landscapes, climate, and to material possessions (Appadurai, 1986; Hooks, 2009). These kinds of attachments are produced through embodiment, for instance, the resonances of smells and tastes, as well as citizenship and property rights (Pfaff-Czarnecka, 2013: 17). It is not only the place as such, but the locality in the sense of a point of social and emotional reference that provides the basis for attachment.

\section{Attachment to Ur: Source of Income and Regaining Lost Status}

Peter De Silva ${ }^{7}$, a Christian-Tamil (43-yr-old) resident at the Gobindpur welfare center in Jaffna, spoke about his attachment to his $U_{r}$ in Myliddi, its fertile soil, its sweet water and the whole landscape. For him, the landscape, which he knows and appreciates, represents home. It means a place where:

\section{"I know people who are around and share the same dialect and the culture... This is how I feel to be attached to my home".}

Peter is not allowed to return to his $U_{r}$ even after almost three decades because of several reasons. He is eagerly waiting to return to his own place as he conceptualizes it to be the source of income. Also, because 'factors like home ownership, length of residence, stages in life-cycle and social relationships', as argued by Mesch and Manor, have ingrained in him an immense sense of attachment to his $U_{r}$ (1998: 505). Therefore, this story depicts his attachment to place as has been rightly put by Hidalgo and Hernandez in their study on 'Place attachment: Conceptual and Empirical Questions', as 'a positive affective bond between an individual and a specific place, the main characteristic of which the tendency of the individual is to maintain closeness to such a place' (2001: 274).

${ }^{7}$ Mr. Peter De Silva was interviewed on February 16, 2013 in Jaffna. He is the President of 9 such welfare centers in the Jaffna District. As already mentioned, Peter is his pseudonym. I have not used his real name for security reasons. 
Besides, there was the opportunity to listen to the stories of a few other IDPs housed in the same welfare center (around 10 of them including both male and female, aged between 35 and 50 years). They, too, are emotionally connected to their home and consider their $U_{r}$ to be amongst the first pieces of information, as having been pointed out by Thiranagama, that they think of introducing themselves to an outsider in terms of their homeland origin, which would reveal their status, character, culture and identity (Thiranagama, 2011: 18).

At this point, Mr. De Silva is not even sure if his home is still there or if the war has destroyed it. They are ready to take the challenge of returning and starting from scratch. It proves their determination and their faith in their land. The government has offered them relocation to another area with the same landscape, but they refused as they do not want to get to a new place that will not be their own and someday they will be again asked to move. So, they want to return to their own home, their land.

"We don't know precisely what the land is being used for..." he stated in a curious voice.

"We are told by the local government officer that the land is being used for a public purpose by the military". From social media, "we have come to know the existence of the 'Thalsewana Holiday Resort' within the region which is functioning under the Security Forces Headquarters. ...we have filed petition to the Sri Lankan High court in order to return to our homes but till now have not got any response".

Peter's home falls under the High Security Zone (HSZ) area which has not yet been opened for the original residents due to several political and economic reasons. However, to a report submitted by the American Association for the Advancement of Science (AAAS) ${ }^{8}$, the government states that the military's acquisition of the HSZ region, encompassing 6,381 acres, or 25 square kilometers of land, is being used for public purposes. Also, the AAAS analysis confirmed the existence of "Thalsewana Holiday Resort" (formerly the Harbour View Hotel) within the military zone which is "functioning under the Security Forces Headquarters." Thus, the government is fooling around by using the name of HSZ to keep the IDPs away from their places of origin. Though the resort ensures local tourists, from other districts, visiting the area quite often, the IDPs cannot gain access into the area to check on their former homes.

Being afraid of losing their homes, IDPs have filed a petition to the Sri Lankan court to get back the land, but have not yet received any reply. At the time of displacement in the 1990s, they were told that their land would be given back with the end of the war, but it has already been more than four years that the war has ended. Still, there is no sign of getting back the land. Therefore, I argue, as did by Thiranagama that, "For Tamils, 'home' was not always synonymous with a Tamil homeland" (2009: 138). Home is the place of origin where one was born and nurtured. It is right for IDPs like Peter who are staying in their homeland but still are eagerly waiting to return to their original places. Besides, he emphasized the economic dimension also:

"We are confident enough, if we return, within a year we will regain our old lives that we enjoyed 30 years back. Also, we will help the government to help the poor with our money. That is the kind of (fertile) land we own. We do not feel hungry at our place. If you sow a seed, within three days it will convert into a tree and you start enjoying its benefits. And our water was like a sugar cane juice, it was that much sweet. From the sea, we had so many different kinds of tasty fishes".

Peter and his fellow neighbors romanticized on the sense of attachment they have to the fertile soil and sweet water, and the degree to which their land meets their needs. The land in Myliddi has been referred by them as Uri land meaning 'diamond land'. ' The most common profession in our area was farming of 'thodi or Palmyra', fish mongos etc". They identify their lands as being their sole source of income and are confident enough that within a year of their return they would be successful in regaining their lost lives that they enjoyed 30 years back. They believe that their lands are so fertile that within three days of sowing seeds they can start their earnings. They would help the government to help the destitute with their money. This expectation represented something that he was confident about. It is only because of these expectations that, people in the camp, are willing to return to their $U_{r}$. Their expectations of leading a good life are totally dependent on their own place. Their place is perceived as meaningful because it offers various kinds of opportunities to earn a livelihood by performing certain activities like farming or fishing, to experience something desirable and also

${ }^{8} \mathrm{http}$ ///www.aaas.org/news/sri-lanka-images-military-zone-reveal-no-significant-increase-public-facilities-aaasreports accessed on April 15, 2018. 
for personal development, which is similar to what Gustafson observed while conducting his own research on the meaning of place in Sweden (2001: 11). Their land provides them with different kinds of tasty fishes and vegetables which are enough for their daily diets. They need not have to spend money on food at their homes. Thus, return will help them to prosper economically as well as. Attachment to his $U_{r}$, thus, concerns "the relationship between self and environment" which is based on the interviewees knowledge of the place (Gustafon: 2001,11) that is so evident here.

Presently, Peter is involved in the same struggle with the same kind of jobs of either masonry or dailywage laborers with his neighbors in which he is highly unskilled. Common acts performed at the welfare centers like sharing the same occupation, is a good example of experiencing commonality. Also, their shared aspirations to have a better future are another way of expressing commonality.

Peter's narrative showed his feeling of 'collective identity' with his fellow neighbors at the welfare center where he mostly used the term 'we' instead of 'I'. He always represented a group of persons who always feel a sense of belonging to their former homes and wanted to return to regain their old lives and social status. Due to this loss in social status, Peter often experienced harassment and discrimination from the locals. "We are recognized as mukam pille [camp people] by the locals", said Peter angrily, but with a grief. Appadurai, has explicitly discussed about the problem of losing social status as a symptom of 'deprivation and desperation. It is lack of security and dignity. It is exposure to risk, high costs and for thin comforts. It is inequality materialized' (2004: 64). The locals, according to Peter, look upon the camp people as lower caste or 'untouchables' (Pfaffenberger, 1981: 1149) even if they used to share the same background of either fishermen or farmer. Their cultures are considered as bad and it is not advisable to the local children to play with the camp children. They fear that playing with the camp people will also make their children ill-cultured. Thus, the camp people see themselves as a group isolated from other locals who are staying either at rented places or at their own houses. In this context, I argue that the local-camp people relationship is very much like that of the Vellalars ${ }^{9}$ and the untouchables. Vellalars, being landholders or farmers, dominate the peninsula's land, economy, political affairs, educational opportunities, foreign exchange remittances and jobs; while the lower caste people are hired to work under their command (Pfaffenberger, 1981: 1150). In addition, the locals speculate that the camp people resent them because of their 'well-off status' as Thiranagama observed in case of the locals and the ahathis [a tamil word which means refugees] in Puttalam but in the opposite way (2011: 149). Therefore, the existence of an ethnic boundary between this two groups comes to the forefront. These boundaries, as according to Barth (1998: 15), are mostly the social ones that 'defines the group, not the cultural stuff that it encloses'. In addition, Barth explains that, 'if a group maintains its identity when members interact with others, this entails criteria for determining membership and ways of signaling membership and exclusion. Ethnic groups are not merely or necessarily based on the occupation of exclusive territories; but by the different ways in which they are maintained, not only by a once-and-for-all recruitment, but by continual expression and validation...' (Barth, 1998: 15).

Peter complained of continual discrimination in the administrative and bureaucratic structures in their area. Thus, identity plays an important role in their life. Their new identity of mukam pille, which can be compared to the status of the untouchables, makes them devoid of many opportunities from their surroundings. Like, when they go to the market to sell their vegetables or fishes, locals avoid buying them because they are bad-cultured people. They are always engaged in fighting and drinking. Also, while filing petitions to the local governments in order to get back their lands, Peter, on many occasions, faced discrimination for being a camp person. Nobody is ready to listen to his pain and sufferings. This specially made him aware of his loss of social status and identity from being an ordinary local to now being from the camp. Therefore, losing his social status made him to feel more attached to his home in Myliddi which can only help him to regain his lost self-esteem.

Nevertheless, the camp people aspire to have a good life in their future which is possible only after returning to their homes. And this has been well argued by Hage when he conceptualizes home as a place to have opportunities in order to enjoy a good life. Here, Hage's argument, "...home must be a space open for opportunities... so that one can perceive opportunities of 'a better life': to develop certain capacities...personal growth... the availability of opportunities for 'advancement' (1997: 103) Therefore, his argument fits well

${ }^{9}$ By the $20^{\text {th }}$ century, the Vellalars emerged numerically as the caste with an absolute majority in the Jaffna peninsula. None of the other castes with any significant numbers was in a position to challenge this numerical preponderance. They control a' large share of the resources in land and other economic activity in the Northern province. Under British rule, they have avidly patronised English education and moved into the clerical, professional and executive positions in the bureaucracy. After independence they have added another prop to their power through electoral politics and a share in political office (Pfaffenberger, 1981). 
with the aspirations of the IDPs, like Peter, in the welfare centers. Aspirations form parts of wider ethical and metaphysical ideas which derive from larger cultural norms. They are always formed in interaction and in the thick of social life. And aspirations about the good life, about health and happiness, exist in all societies though they might vary from people to people.

Besides, Peter also gives salience to having space around him, and that is an important reason why he wants to return. The use of space connects him to a traditional way of using it, but often gets transformed into a leisure activity and symbol of life style. He remembers his own good childhood at his home and wants to give his children a similar one, but "Alas!", murmured Peter as he knew that it is not possible.

"We owned a big one-storied house with a huge lawn in front.... Hundreds of coconut and Palmyra trees were there in front of our house... But now 146 families live in 70 perch $^{10}$ of land... so you can well imagine how small is our habitable place now".

His $U_{r}$ forms the basis of his identity. In his native place, individuals claim to own vast acres of land where they own big house along with enough farming land. Together with his neighbors, the landscapes have been shaped through their farming activities and by their "neighborly care, assistance, and control" as discussed by De Sales (2011: 4) in her article. Here, Peter's social ties to his neighbors and friends living in the neighborhood are critical to the understanding of his attachment to home. This development of affection towards his home is also the result of the relationships with other people in his neighborhood. As according to Low and Altman (1992), places are the circumstances where the interpersonal relationship takes place, and people get attached to those social relationships. Supporting this argument, Mesch and Manor have shown that 'local social involvement, in particular with friends and kin, is the most consistent and significant source of attachment to place' (1998: 507).

The links to his homeland exist in the appreciation of the surroundings, in the experiences of shaping the natural environment, in the legal entitlements to land, in the imaginations of being formed by the local topography and by the original set-up as well as by the many experiences of performing commonality and mutuality through local practices. All these have become past tense as it has already been more than three decades that he has been away from his home and been displaced. The suffering caused by the displacement has developed a sense of attachment even stronger. In this scenario, the agony of losing his homeland becomes all the more unbearable as displacement not only meant abandoning possessions and the relationships but also losing "dense social ties, solidarity and support" (Mesch and Manor, 1998: 507). Ur, to him, has become "an object of longing (inherent in 'belonging')" (Mesch and Manor, 1998: 507).

Besides, according to Peter and his fellow neighbors, their camp-life has become even worse in the last four years with the end of the war. The camps are very densely populated thus creating poor sanitary conditions. The extreme overcrowding, together with lack of access to clean water, sufficient food, and health care services, had a considerable impact on their health. They also complained about the minimal scope of education for camp children, the prevalence of harmful diseases due to the presence of different kinds of insects, drunkenness, and lack of privacy for young girls. Despite the deployment of the military to provide protection, the IDPs, as jointly stated, commonly experience violence and abuse at the hands of the military forces who are supposed to protect them.

To add to their difficulties, since 2011 the government and the NGOs have ceased to provide dry food rations and other basic supports. And due to this, the camp people are unable to live a decent life at the camps. Bringing up their children amidst the camp is also a matter of concern for them. Moreover, they are also worried because of the opening of the A9 highway ${ }^{11}$ which is the main reason for the young generations of getting addicted to alcohols and drugs. "Government has asked the Government Agents of our regions not to provide any kind of help to us", uttered one of the displaced in total dismay. "We cannot live a decent life in the camps, cannot bring up our little children in a good way. With the transformation in status, our culture has also changed. All have become selfish", said Peter in a very depressed tone. In addition to these, "With the opening of the A9 road, consumption of alcohols, drugs have increased. Mostly, young generations, in between the age of 15-25 are addicted towards these habits. Main reason is that they want to lead a jolly and entertaining life". Because of the poverty, unemployment and lack of proper guidance, young boys and girls are taking the wrong path. They feel that they do not have choices and it made them angry. They also showed the negative impacts that, once quiet and peaceful, Jaffna has been witnessing at present.

${ }^{10} 1$ Perch $=0.00625$ acres.

${ }^{11}$ A9 is the main road which connects Jaffna with the city of Kandy. It is categorized as 'A' as it complements a highway in the country (Chattoraj 2017). 
"Most of the parents work outside leaving behind their daughters in the camps. This gives room to outsiders to come and spend time with the young ones which many a times leads to unwanted pregnancy, kidnappings. Also, young unmarried couples within the camps, wishing to have fun, leads to unwanted pregnancy. Peter also said that there is an increase in the number of unwanted pregnancies at the camps as most of the parents work outside leaving behind their daughters in the camps. This allows outsiders to enter their houses leading to those pregnancies. Peter's statement proved to be correct when visitation a couple of welfare centers in Jaffna, and often came across young girls aged between 14-17 years roaming with their kids. It took me by great surprise to see these girls, instead of going to schools, are raising up their children. Among them, most are unmarried which is an uncultured practice in Jaffna. Adults also expressed their concern about these uncultured practices by their children. They further added that the basic relationships that used to hold families and villages together have been totally lost in the post-war days.

Children are being left alone in the camps by their parents as both the parents are going to work outside with the aim to earn some extra money to lead a decent life. This negligence was described, by the parents, in material, social and emotional terms. Material neglect occurs due to parents' poverty and some interviewees said that children do not benefit from the parental care and guidance they would have received before displacement. The quality of the education children receive at schools has gone down, and many are unable to pay the fees to send their children to school. Some even talked about a decrease in respect for traditional practices and behavior, and difficulty in finding ways to pass their culture onto the youth. It is because, as shown by Pfaffenberger (1981: 1147) in his essay on the culture of Tamil separatism, the Ceylon Tamils, particularly those from Jaffna, consider themselves to be a unique people, differing in their customs and their heritage from the other group of Tamils. Therefore, they believe that it is their responsibility to preserve and protect their ancient culture and traditions.

On the other hand, young generations are said to suffer from idleness and lack of constructive activity, related to both a lack of access to the education system and a lack of space for children and youths to engage in leisure activities, such as sports and traditional dance. Idleness is perceived to contribute to sexual promiscuity, criminal behavior, and alcohol abuse. Alcohol abuse is believed to have serious consequences, including promiscuity and violence (e.g., fighting, domestic violence, sexual abuse, and assault). Interviewees complained that young people are sexually promiscuous due to factors such as population congestion, poverty, and parental neglect. It, in turn, has health consequences regarding sexually transmitted infections, and unwanted pregnancies.

Nevertheless, it is only because of the expectation of leading a good life, Peter and his fellow neighbors, are willing to return to their $U r$. Their expectations can only be fulfilled after returning to their place, as they believe home is made up of a pleasant environment and a good and respected life. In this context, their site is perceived as being mean because it offers an essential life with various kinds of opportunities to earn a livelihood by performing certain activities like farming and fishing, experiencing something desirable and also opportunities for personal development. Attachment to his place thus concerns "the relationship between self and environment," as stated by Gustafson, which is based on the interviewee's knowledge of the place that is so evident here (Gustafson, 2001: 11). Thus, the decision to return to $U_{r}$ is influenced by the socio-economic needs, aspirations to the good life and regaining his lost social status.

\section{Conclusion}

In this article, I have demonstrated how the Sri Lankan IDPs at the welfare centers express attachment to their $U_{r}$. 'Home' is considered an emotional attachment to the territory as has been argued by Chattoraj (2018). I argue that the 'attachment to home' implies a positive affective bond where an individual must maintain closeness to a specific place. This statement holds in the case of Peter. He and his fellow neighbors are attached to their $U_{r}$ as they are eagerly waiting to return even after two decades. Home, to them, is a source of income which will fetch enough money, from farming and fishing, to lead a good life. They will also regain their lost identities. This narrative exhibits a diverse range of attachment to home through the place, people and memories. Thus, it becomes a way of talking about social, cultural, economic and personal attachment, as illustrated by the narratives recounted here. The attachment that the IDPs ascribe to their homes come from spatially encodes social and cultural attachments as described by Wiborg (2004). However, she asserts that living in a place is not a necessary condition for belonging to it (429) as is depicted in the narratives of Peter and his fellow neighbors. Even though they are away from their homes, but they still have a strong sense of attachment to their $U_{r}$ and are waiting to return as soon as possible. Therefore, arguing about the meaning of $U_{r}$ and attachment to it has remained unchanged for this group of population in Jaffna due to socio-economic reasons and aspirations to a good life. 


\section{References}

Ainsworth, M.S. "Infant-Mother Attachment." American Psychologist 34, no. 10 (1979): 932-937.

Appadurai, A. "The Capacity to Aspire". In Rao V. and Walton PA (eds) Culture and Public Action. Stanford University Press, 2004.

Appadurai, A. The Social Life of Things: Commodities and the Politics of Value. Cambridge: Cambridge University Press, 1986.

Barth, F. Introduction. In Barth F. (ed.), Ethnic Groups and Boundaries. The Social Organization of Culture Difference. Illinois: Waveland Press, 1969.

Bowlby, J. Attachment and Loss. New York: Basic Books, 1969.

Chattoraj, D. "Ambivalent Attachments: shifting notions of home among displaced Sri Lankan Tamils." (PhD dissertation, 2017.

Chattoraj, D. "Experiences of Sri Lankan Tamils Displaced to Colombo: Three Narratives." eTropic: Electronic Journal of Studies in the Tropics 17, no. 1 (2018): 137-148.

Cheran, R. "Citizens of many worlds: theorizing Tamil Diasporic City". In Cheran, R. D. Ambalavanar and C. Kanaganayakam (eds.), History and Imagination: Tamil Culture in the Global context. Toronto: TSAR, 2007.

Cresswell, J. W. Research Design: Qualitative, Quantitative and Mixed Methods Approaches. Sage Publications, 2003.

Daniel, E. V. Fluid signs: Being a person the Tamil way. Univ of California Press, 1984.

De Sales A. "Hamro Gaon: Practices of Belonging in Rural Nepal." In Pfaff-Czarnecka, J., \& Toffin, G. (eds) The Politics of Belonging in the Himalayas: Local Attachments and Boundary Dynamics, Vol-4 Sage Publications: New Delhi, 2011.

Gustafson, P. "Meanings of Place: Everyday Experience and Theoretical Conceptualizations." Journal of Environmental Psychology 21, no. 1 (2001): 5-16.

Hage, G. At Home in the Entrails of the West: Multiculturalism, Ethnic Food and Migrant Home-building. Home/world: Space Community and Marginality in Sydney's West, 1997.

Hooks, B. Belonging: A Culture of Place. New York: Routledge, 2009.

Kvale, S. Interviews: An Introduction to Qualitative Research Interviewing. California: Sage, 1996.

Low, S. and Altman, I. "Place Attachment: A Conceptual Inquiry". In Altman, I. and Low, S. (eds.), Place Attachment. New York: Plenum, 1992.

Mesch, G. S. and Manor, O. "Social Ties, Environmental Perception, and Local Attachment." Environment and Behavior 30, no. 4 (1998): 504-519.

Pfaff-Czarnecka, J. Multiple belonging and the challenges to biographic navigation. Max-Planck-Institut zur Erforschung multireligiöser und multiethnischer Gesellschaften, 2013.

Pfaffenberger, B. "The Cultural Dimension of Tamil Separatism in Sri Lanka." Asian Survey 21, no. 11 (1981):1145-1157.

Pickbourn, L. J. "Migration, Remittances and Intra-household Allocation in Northern Ghana: Does Gender Matter?" PhD Dissertation, University of Massachusetts Amherst.

Scheyvens, R. ed. Development fieldwork: A Practical Guide. London: Sage, 2014.

Thiranagama, S. In My Mother's House: Civil War in Sri Lanka. University of Pennsylvania Press, Philadelphia, 2011.

Wiborg, A. "Place, Nature and Migration: Students' Attachment to Their Rural Home Places." Sociologia Ruralis 44, no. 4: 416-432. 